\title{
Inisiasi Perkiraan Arah Pergerakan Alur Sungai
}

\author{
Kuntjoro, Choirul Anwar, Pudiastuti, Didik Harijanto, Sungkono \\ Program Studi Diploma Teknik Sipil FTSP ITS, Surabaya \\ Email: kuntjoro_rivers@yahoo.co.id
}

\begin{abstract}
The natural conditions of the river have no perfectly straight lane. It is tightly because every river has always been influenced by dynamic balance in the stream. The balance lies between erosion and sedimentation that occurs in catchment area of the river and along the river. Meanwhile, erosion and sedimentation themselves are influenced by many factors that primarily include the discharge occured, soil type and geometry of the river. This paper only discusses one segment of a river with the review towards seventeen cross sections with the determined geometries. The discharge was expressed in the river's water level elevation observed in three conditions i.e. 4.5 meters, 3.0 meters and 2.0 meters.

The estimation the direction and geometric change of the river were made to analyze the complex process of event erosion and deposition on the base and on the banks of the river. Quantity of sediment from erosion of the side banks was calculated by means of Meyer-Piter-Muler (MPM) method. While the sediment from the collapse of a side banks was calculated with equation $q_{b r}^{f}=\bar{\xi} \Delta h_{b a n k}(1-p)$.

The biggest degradation occurred on a side banks with the greatest angle of slope and lied in the outer part of cross section. Meanwhile, the biggest aggradations did not always occur on a side banks with the smallest and slopes and lied in the inner part of the cross section. In fact, it also might be in an alternating condition i.e. degradation occurred in the water depth of $h=4.5$ meters and aggradations was at a water depth of 3.0 or 2.0 meters.
\end{abstract}

Keywords: movement direction of groove, meanders, river

Abstrak

Kondisi alamiah sungai tidak ada yang lurus sempurna, karena setiap sungai selalu dipengaruhi oleh keseimbangan dinamis di dalam sungai. Keseimbangan tersebut adalah antara erosi dan sedimentasi yang terjadi di daerah aliran sungai dan di sepanjang alur sungai. Sedangkan erosi dan sedimentasi sendiri dipengaruhi banyak faktor, yang terpenting adalah debit yang terjadi, jenis tanah dan geometri sungai. Dalam makalah ini hanya dibahas satu segmen sungai yang dengan tinjauan tujuh belas cross section dengan geometri yang telah ditentukan, debit yang terjadi dinyatakan dalam elevasi muka air di sungai ditinjau tiga kondisi yaitu 4.5 meter, 3.0 meter, dan 2.0 meter.

Perkiraan arah pergerakan dan perubahan geometri sungai dibuat untuk menganalisis proses yang kompleks dari peristiwa gerusan dan pengendapan didasar dan ditebing sungai. Besaran sedimen dari erosi tebing dihitung dengan menggunakan metode Meyer-Piter-Muler (MPM). Sedangkan sedimen dari keruntuhan tebing dihitung dengan persamaan $q_{b r}^{f}=\bar{\xi} \Delta h_{b a n k}(1-p)$.

Degradasi terbesar pada tebing dengan sudut lereng terbesar dan berada pada cross section bagian luar. Agradasi terbesar tidak selalu pada tebing dengan sudut lereng terkecil dan berada pada pada cross section bagian dalam. Tetapi biasa juga terjadi kondisi bolak-balik yaitu terjadi degradasi pada kedalaman air $h=4.5$ meter dan agradasi pada kedalaman air 3.0 atau 2.0 meter.

Kata Kunci: arah pergerakan alur, meander, sungai.

\section{Pendahuluan}

Pada umumnya, dalam segmen sungai dengan bentuk lengkung, struktur ali- rannya akan rumit karena adanya ketidakseragaman aliran ke arah samping (lateral). Analisis dapat dilakukan de-

Jurnal APLIKASI: Media Informasi \& Komunikasi Aplikasi Teknik Sipil Terkini Halaman 47 
ngan menggunakan rata-rata vertikal yaitu dengan persamaan-persamaan yang masih mengandung variasi aliran lateral.

Penyelesaian secara umum harus menggunakan persamaan secara utuh dan memerlukan perhitungan yang rumit yang bisa diselesaikan dengan bantuan metode numerik. Hal ini bisa dilakukan dengan penyederhanaan dengan mengasumsikan bahwa kedalaman air $h$ yang besarnya ditentukan mendekati konstan. Kondisi yang demikian ini berarti aliran merupakan aliran tunak (steady). Oleh karena penelitian ini akan membahas pergerakan alur sungai akibat fluktuasi debit, maka setiap kondisi debit dianggap sebagai aliran tunak sesaat.

Fluktuasi debit merupakan peristiwa alam yang diindikasikan dengan adanya tinggi rendahnya muka air di sungai. Masalah yang bisa dirumuskan dalam penelitian ini adalah:

1. Arah pergerakan alur sungai bermeander.

2. Besaran perubahan geometri sungai.

Sesuai dengan latar belakang yang telah diuraikan di atas, tujuan analisis ini adalah untuk menentukan arah perubahan geometri sungai akibat perubahan debit.

Banyak kasus yang terjadi dilapangan yang berhubungan arah dan besar pergerakan sungai. Manfaat dari penelitian ini adalah arah pergerakan alur sungai yang dihasilkan dari penelitian ini bisa dipakai sebagai dasar perencanaan penentuan letak posisi bangunan sungai.

\section{Metodologi}

\subsection{Prinsip Dasar Pergerakan Alur Sungai}

Prinsip dasar perubahan alur sungai akibat perubahan debit adalah dimensi sungai pada lengkung yang ditunjukkan pada gambar 1 dengan kondisi-kondisi khusus sebagai berikut:

\section{a. Kondisi 1}

Pada sudut $\theta=0$ sampai dengan $\theta=$ $\phi$ sungai dalam kondisi seimbang, sehingga penampang melintang sungai masih dalam kondisi normal.

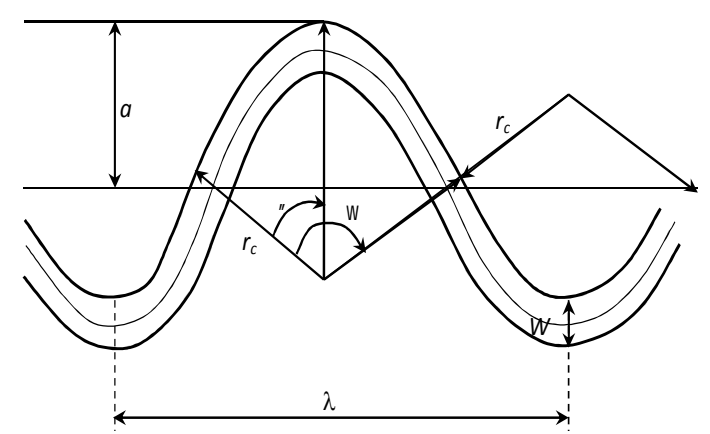

Gambar 1. Definisi geometri meander menurut Hey

\section{b. Kondisi 2}

Pada saat sudut $\theta=0$ - $\phi$ sungai dalam kondisi tebing tergerus sebelah kiri dan sedimentasi sebelah kanan.

c. Kondisi 3

Setelah melewati kondisi ini sehingga dicapai $\theta>\phi$, kondisi penampang sungai menjadi kebalikan dari kondisi 2.

Perubahan dimensi sungai dan pergeseran alur merupakan fungsi dari: kondisi tanah pembentuk tebing dan dasar sungai; debit sungai; dimensi sungai dan parameter meander.

\subsection{Pendekatan Empiris Pergerakan Alur Sungai}


Pendekatan empirik perubahan geometri sungai dalam penelitian ini adalah modifikasi dari metode diskritisasi J. G. Duandan P.Y. Julien (2005). Penerapan metode empiris dari data pengukuran debit dan data ukur cross section sungai dikembangkan dari diskritisasi J.G. Duan (2005). Pergerakan alur sungai di analisis dari pergerakan setiap titik pada setiap cross section.

Setiap titik ditandai dengan node $(x i, y i)$ dimana $i=1 \ldots . n$, setiap detik debit lewat melalui titik-titik ini, setiap titik akan bergerak bergeser ke arah (xi', $\left.y i^{\prime}\right)$, pergerakan dari (xi, yi) menjadi $\left(x i^{\prime}, y i{ }^{\prime}\right)$ terjadi pergeseran sebesar $(\Delta x i, \Delta y i)$. Dimana $\Delta x i$ adalah jarak pergerakan horizontal titik $x i$ ke arah $x i$ ' dan $\Delta y i$ adalah jarak pergerakan titik $y i$ ke arah $y i$ '. Setiap titik dari data pengukuran yang ditinjau $(x i, y i)$ setiap detik akan bergeser menjadi ( $\left.x i^{\prime}, y i^{\prime}\right)$ dengan $\operatorname{jarak}(\Delta x i, \Delta y i)$.

\section{Hasil dan Pembahasan}

\subsection{Fluktuasi Debit}

Fluktuasi debit dalam penelitian ini ditinjau tiga kondisi perubahan debit yang menggambarkan tiga perubahan muka air yaitu kondisi elevasi muka air $\mathrm{h}=4.5$ meter, 3.0 meter, dan 2.0 meter. Pembahasan yang lebih detail seharusnya didasarkan pada hubungan fluktuasi debit tersebut terhadap fluktuasi muka air, namun dalam bahasan ini langsung meninjau tiga kondisi muka air tersebut.

Pada ketiga kondisi tersebut kemudian dihitung besaran perubahan/pergeseran tebing sungai pada tujuh belas potongan melintang (cross section) di tiap-tiap titik (point node) pada cross section tersebut.

\subsection{Lengkung Meander}

Didasarkan pada sinuositas dan karakteristik lainnya, pola sungai digolongkan menjadi: sungai lurus, sinous, meander, dan menjalin (Morisawa 1985). Sinuositas adalah perbandingan antara panjang sungai terhadap panjang as meander. Suatu sungai bermeander adalah sungai dengan sinuositas lebih besar dari 1.5 dan jika sungai berada pada satu rangkaian lengkung meander dalam sungai yang sama, maka meander sungai berada di antara dua titik balik (Julien 2002).

Meander sungai yang ditinjau dalam penelitian ini dinyatakan dalam koordinat sumbu kartesian titik-titik tanggul kiri dan kanan serta as sungai. Yang terdiri dari tujuh belas cross section seperti yang terlihat pada tabel 1, yang mana titik-titik koordinat tersebut digambarkan sebagai denah alur sungai bermeander seperti yang terlihat pada gambar 2.

Masing-masing cross section pada alur meander kemudian digambarkan sebagai cross section Nomor 1 sampai dengan 17 yang ditunjukkan hanya dua cross section yaitu 16 dan 17 seperti yang terlihat pada gambar 3 .

\subsection{Sedimen Erosi Tebing dan Dari Keruntuhan Tebing}

Besaran sedimen dari erosi tebing dihitung dengan menggunakan metode Meyer - Piter - Muler (MPM) dengan persamaan berikut: $S=\Phi\left(g \cdot \Delta \cdot D m^{3}\right)^{1 / 2}$. 
Sedangkan sedimen dari keruntuhan tebing dihitung dengan persamaan berikut: $q_{b r}^{f}=\bar{\xi} \Delta h_{\text {bank }}(1-p)$. Hasil perhitungan untuk tinggi air $\mathrm{h}=4.5$ meter dinyatakan dalam tabel 2; untuk tinggi air $\mathrm{h}=3.0$ meter ditunjukkan dalam Tabel 3 dan untuk tinggi air $\mathrm{h}=2$ meter pada tabel 4.

Tabel 1. Koordinat Titik-titik Cross Section

\begin{tabular}{ccccc}
\hline No. Cross & $\mathrm{X}$ & $\mathrm{Y}$ as & $\mathrm{Y}$ kiri & $\mathrm{Y}$ kanan \\
\hline 1 & 850.00 & 88.07 & 140.57 & 35.57 \\
\hline 2 & 1015.63 & -65.51 & -15.51 & -115.51 \\
\hline 3 & 11881.25 & -169.68 & -116.68 & -222.68 \\
\hline 4 & 1346.88 & -220.35 & -169.35 & -271.35 \\
\hline 5 & 1512.50 & -221.09 & -166.09 & -276.09 \\
\hline 6 & 1678.13 & -181.27 & -121.27 & -261.27 \\
\hline 7 & 1843.75 & -114.25 & -44.25 & -184.25 \\
\hline 8 & 2009.38 & -35.51 & 39.49 & -100.51 \\
\hline 9 & 2175.00 & 39.20 & 99.20 & -20.80 \\
\hline 10 & 2340.63 & 95.65 & 165.65 & 25.65 \\
\hline 11 & 2506.25 & 123.01 & 193.01 & 63.01 \\
\hline 12 & 2671.88 & 115.68 & 185.68 & 50.68 \\
\hline 13 & 2837.50 & 75.12 & 175.12 & -34.88 \\
\hline 14 & 3003.13 & 11.70 & 81.70 & -88.30 \\
\hline 15 & 3168.75 & -53.45 & 26.55 & -153.45 \\
\hline 16 & 3334.38 & -86.63 & -6.63 & -175.63 \\
\hline 17 & 3500.00 & -39.72 & 40.28 & -119.72 \\
\hline
\end{tabular}

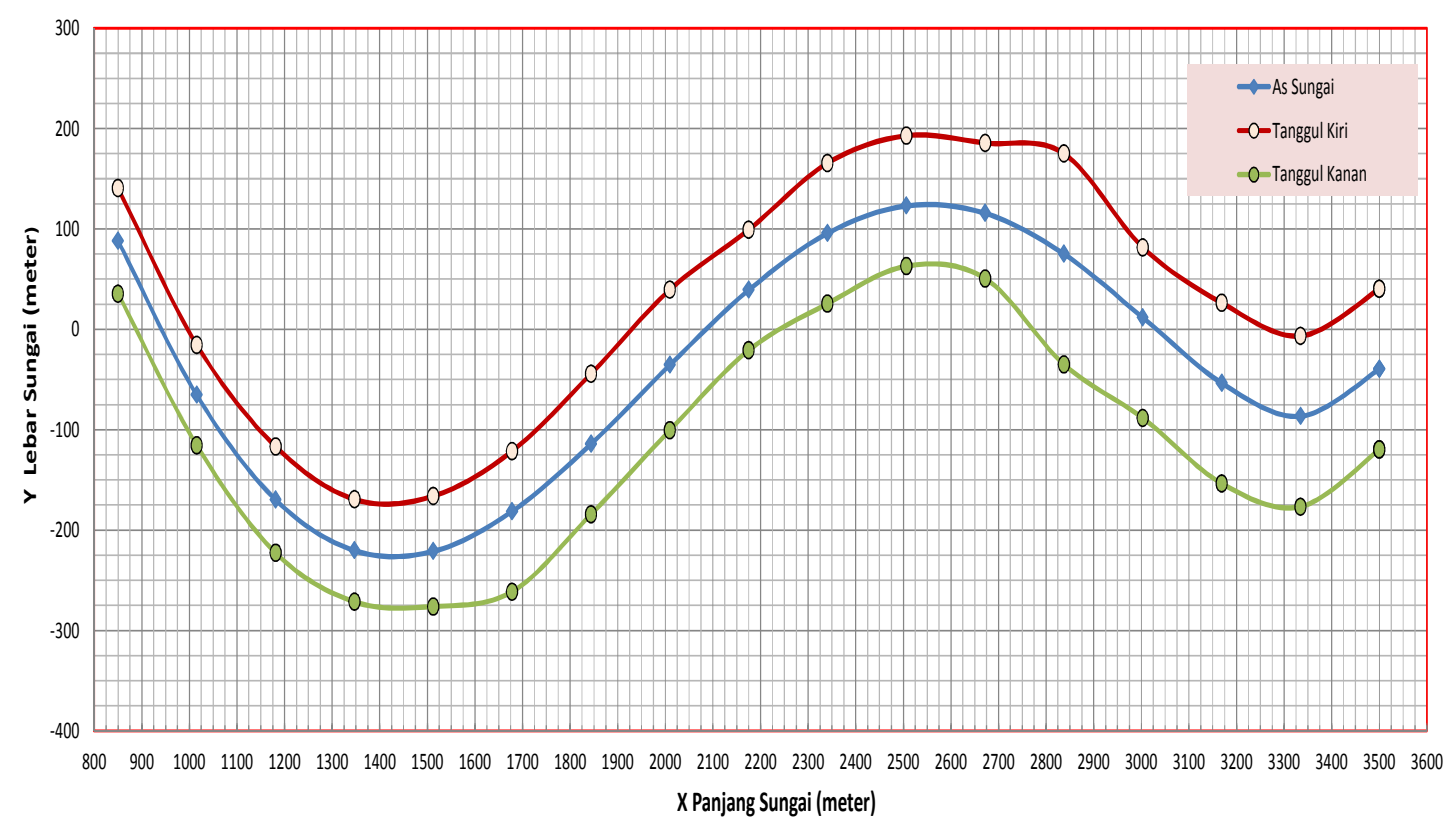

Gambar 2. Lengkung Meander Sungai 
(a)
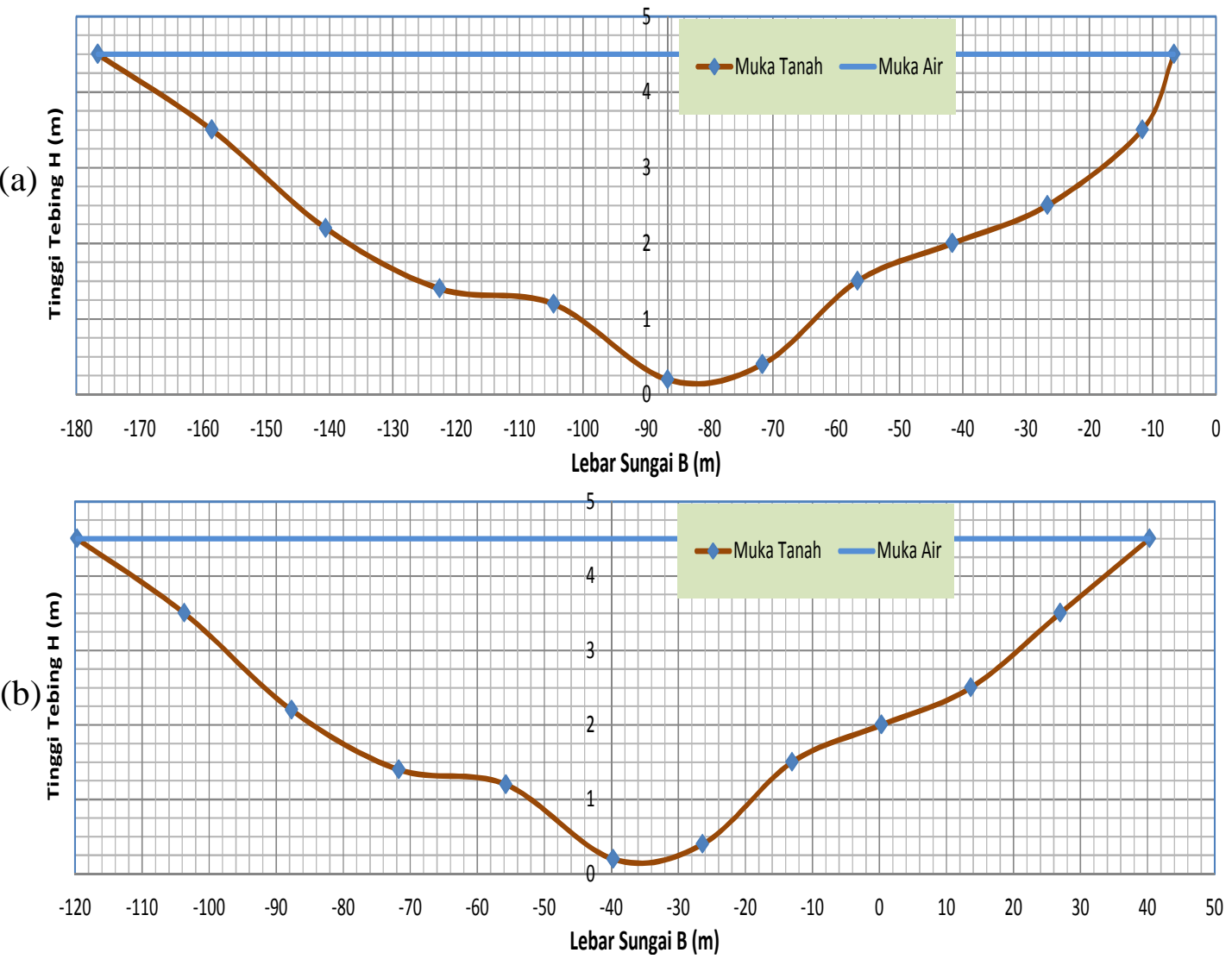

Gambar 3. Cross Section Sungai Nomer 16 (a) dan 17 (b)

Tabel 2. Komponen transversal laju angkutan sedimen pada tinggi air $\mathrm{h}=4.5$ meter

\begin{tabular}{ccccc}
\hline $\mathrm{h}_{\mathrm{b}}$ & $\mathrm{S}\left(\mathrm{m}^{3} / \mathrm{dt} / \mathrm{m}^{\prime}\right)$ & $\Delta \mathrm{h}_{\text {bank }}$ & $\mathrm{q}_{\mathrm{br}}^{\mathrm{f}}\left(\mathrm{m}^{3} / \mathrm{dt} / \mathrm{m}^{\prime}\right)$ & $\mathrm{q}_{\mathrm{br}}\left(\mathrm{m}^{3} / \mathrm{dt} / \mathrm{m}\right)$ \\
\hline 5.00 & 0.00001 & 0.00 & 0.00000 & 0.00001 \\
\hline 4.75 & 0.00001 & 0.25 & 0.00002 & 0.00003 \\
\hline 4.50 & 0.00001 & 0.50 & 0.00013 & 0.00014 \\
\hline 4.25 & 0.00001 & 0.75 & 0.00047 & 0.00048 \\
\hline 4.00 & 0.00027 & 1.00 & 0.00120 & 0.00147 \\
\hline 3.75 & 0.00022 & 1.25 & 0.00253 & 0.00275 \\
\hline 3.50 & 0.00002 & 1.50 & 0.00470 & 0.00472 \\
\hline 3.25 & 0.00131 & 1.75 & 0.00795 & 0.00926 \\
\hline 3.00 & 0.00002 & 2.00 & 0.01251 & 0.01254 \\
\hline 2.75 & 0.00006 & 2.25 & 0.01860 & 0.01866 \\
\hline 2.50 & 0.00002 & 2.50 & 0.02638 & 0.02640 \\
\hline 2.25 & 0.00002 & 2.75 & 0.03597 & 0.03598 \\
\hline 2.00 & 0.00001 & 3.00 & 0.04742 & 0.06070 \\
\hline 1.75 & 0.00000 & 3.25 & 0.06070 & 0.07569 \\
\hline 1.50 & 0.00000 & 3.50 & 0.07569 & 0.09248 \\
\hline 1.25 & 0.00000 & 3.75 & 0.09218 & 0.10987 \\
\hline 1.00 & 0.00000 & 4.00 & 0.10987 & 0.12837 \\
\hline 0.75 & 0.00000 & 4.25 & 0.12837 & 0.13592 \\
\hline 0.50 & 0.00000 & 4.50 & 0.13592 & 0.14347 \\
\hline 0.25 & 0.00000 & 4.75 & 0.14347 & \\
\hline
\end{tabular}


Tabel 3. Komponen transversal laju angkutan sedimen pada tinggi air $\mathrm{h}=3.0$ meter

\begin{tabular}{ccccc}
\hline $\mathrm{h}_{\mathrm{b}}$ & $\mathrm{S}\left(\mathrm{m}^{3} / \mathrm{dt} / \mathrm{m}^{\prime}\right)$ & $\Delta \mathrm{h}_{\text {bank }}$ & $\mathrm{q}_{\mathrm{br}}^{\mathrm{f}}\left(\mathrm{m}^{3} / \mathrm{dt} / \mathrm{m}^{\prime}\right)$ & $\mathrm{q}_{\mathrm{br}}\left(\mathrm{m}^{3} / \mathrm{dt} / \mathrm{m}^{\prime}\right)$ \\
\hline 5.00 & 0.00000 & 0.00 & 0.00000 & 0.00000 \\
\hline 4.75 & 0.00000 & 0.25 & 0.00000 & 0.00000 \\
\hline 4.50 & 0.00000 & 0.50 & 0.00003 & 0.00003 \\
\hline 4.25 & 0.00000 & 0.75 & 0.00011 & 0.00011 \\
\hline 4.00 & 0.00011 & 1.00 & 0.00028 & 0.00039 \\
\hline 3.75 & 0.00009 & 1.25 & 0.00058 & 0.00067 \\
\hline 3.50 & 0.00000 & 1.50 & 0.00108 & 0.00108 \\
\hline 3.25 & 0.00055 & 1.75 & 0.00183 & 0.00238 \\
\hline 3.00 & 0.00001 & 2.00 & 0.00289 & 0.00290 \\
\hline 2.75 & 0.00002 & 2.25 & 0.00429 & 0.00432 \\
\hline 2.50 & 0.00001 & 2.50 & 0.00609 & 0.00610 \\
\hline 2.25 & 0.00001 & 2.75 & 0.00830 & 0.00831 \\
\hline 2.00 & 0.00000 & 3.00 & 0.01094 & 0.01094 \\
\hline 1.75 & 0.00000 & 3.25 & 0.01401 & 0.01401 \\
\hline 1.50 & 0.00000 & 3.50 & 0.01747 & 0.01747 \\
\hline 1.25 & 0.00000 & 3.75 & 0.02127 & 0.02127 \\
\hline 1.00 & 0.00000 & 4.00 & 0.02535 & 0.02535 \\
\hline 0.75 & 0.00000 & 4.25 & 0.02962 & 0.02962 \\
\hline 0.50 & 0.00055 & 4.50 & 0.03137 & 0.03191 \\
\hline 0.25 & 0.00055 & 4.75 & 0.03311 & 0.03366 \\
\hline
\end{tabular}

Tabel 4. Komponen transversal laju angkutan sedimen pada tinggi air $\mathrm{h}=2.0$ meter

\begin{tabular}{ccccc}
\hline $\mathrm{h}_{\mathrm{b}}$ & $\mathrm{S}\left(\mathrm{m}^{3} / \mathrm{dt} / \mathrm{m}^{\prime}\right)$ & $\Delta \mathrm{h}_{\text {bank }}$ & $\mathrm{q}_{\mathrm{br}}^{\mathrm{f}}\left(\mathrm{m}^{3} / \mathrm{dt} / \mathrm{m}^{\prime}\right)$ & $\mathrm{q}_{\mathrm{br}}\left(\mathrm{m}^{3} / \mathrm{dt} / \mathrm{m}^{\prime}\right)$ \\
\hline 5.00 & 0.00000 & 0.00 & 0.00000 & 0.00000 \\
\hline 4.75 & 0.00000 & 0.25 & 0.00002 & 0.00002 \\
\hline 4.50 & 0.00000 & 0.50 & 0.00013 & 0.00013 \\
\hline 4.25 & 0.00000 & 0.75 & 0.00047 & 0.00047 \\
\hline 4.00 & 0.00007 & 1.00 & 0.00120 & 0.00126 \\
\hline 3.75 & 0.00005 & 1.25 & 0.00253 & 0.00258 \\
\hline 3.50 & 0.00000 & 1.50 & 0.00470 & 0.00470 \\
\hline 3.25 & 0.00033 & 1.75 & 0.00795 & 0.00828 \\
\hline 3.00 & 0.00000 & 2.00 & 0.01251 & 0.01251 \\
\hline 2.75 & 0.00001 & 2.25 & 0.01860 & 0.01861 \\
\hline 2.50 & 0.00001 & 2.50 & 0.02638 & 0.02639 \\
\hline 2.25 & 0.00000 & 2.75 & 0.03597 & 0.03597 \\
\hline 2.00 & 0.00000 & 3.00 & 0.00080 & 0.00080 \\
\hline 1.75 & 0.00000 & 3.25 & 0.00202 & 0.00202 \\
\hline 1.50 & 0.00000 & 3.50 & 0.00419 & 0.00419 \\
\hline 1.25 & 0.00000 & 3.75 & 0.00759 & 0.00759 \\
\hline 1.00 & 0.00000 & 4.00 & 0.01253 & 0.01253 \\
\hline 0.75 & 0.00000 & 4.25 & 0.01930 & 0.01930 \\
\hline 0.50 & 0.00033 & 4.50 & 0.02815 & 0.02848 \\
\hline 0.25 & 0.00033 & 4.75 & 0.03926 & 0.03959 \\
\hline
\end{tabular}


3.4. Maju dan Mundurnya Garis Tebing

Hasil perhitungan maju dan mundurnya garis tebing sungai untuk tinggi air $\mathrm{h}=$
4.5 meter dinyatakan dalam tabel $5 ; \mathrm{h}=$ 3 meter pada tabel 6 dan $\mathrm{h}=2$ meter pada tabel 7.

Tabel 5. Maju dan mundurnya garis tebing pada tinggi air $\mathrm{h}=4.5$ meter

\begin{tabular}{ccccccc}
\hline No. titik & $\mathrm{h}_{\mathrm{b}}$ & $\mathrm{d}_{\mathrm{r}}$ & $\mathrm{q}_{\mathrm{br}}$ & $\Delta \mathrm{r}$ & $\varepsilon_{\mathrm{i}, \mathrm{j}}$ & $\Delta \mathrm{B}_{1, \mathrm{j}}$ \\
\hline 1 & 4.75 & 0.5 & 0.0000 & 3 & 0.000 & 0.00002 \\
\hline 2 & 4.50 & 0.4 & 0.0001 & 3 & 0.000 & 0.00014 \\
\hline 3 & 4.25 & 0.3 & 0.0005 & 3 & 0.000 & 0.00047 \\
\hline 4 & 4.00 & 0.2 & 0.0015 & 3 & 0.001 & 0.00146 \\
\hline 5 & 3.75 & 0.4 & 0.0028 & 3 & 0.003 & 0.00274 \\
\hline 6 & 3.50 & 0.6 & 0.0047 & 3 & 0.005 & 0.00471 \\
\hline 7 & 3.25 & 0.8 & 0.0093 & 3 & 0.009 & 0.00925 \\
\hline 8 & 3.00 & 1.0 & 0.0125 & 3 & 0.013 & 0.01253 \\
\hline 9 & 2.75 & 1.2 & 0.0187 & 3 & 0.019 & 0.01865 \\
\hline 10 & 2.50 & 1.4 & 0.0264 & 3 & 0.026 & 0.02639 \\
\hline 11 & 2.25 & 1.6 & 0.0360 & 3 & 0.036 & 0.03598 \\
\hline 12 & 2.00 & 1.8 & 0.0474 & 3 & 0.047 & 0.04742 \\
\hline
\end{tabular}

Tabel 6. Maju dan mundurnya garis tebing pada tinggi air $\mathrm{h}=3.0$ meter

\begin{tabular}{ccccccc}
\hline No. titik & $\mathrm{h}_{\mathrm{b}}$ & $\mathrm{d}_{\mathrm{r}}$ & $\mathrm{q}_{\mathrm{br}}$ & $\Delta \mathrm{r}$ & $\varepsilon_{\mathrm{i}, \mathrm{j}}$ & $\Delta \mathrm{B}_{1, \mathrm{j}}$ \\
\hline 1 & 4.75 & 0.5 & 0.0000 & 0.17 & 0.000 & 0.00000 \\
\hline 2 & 4.50 & 0.4 & 0.0000 & 0.13 & 0.000 & 0.00003 \\
\hline 3 & 4.25 & 0.3 & 0.0001 & 0.10 & 0.000 & 0.00011 \\
\hline 4 & 4.00 & 0.2 & 0.0004 & 0.07 & 0.000 & 0.00038 \\
\hline 5 & 3.75 & 0.4 & 0.0109 & 0.13 & 0.011 & 0.01094 \\
\hline 6 & 3.50 & 0.6 & 0.0140 & 0.20 & 0.014 & 0.01401 \\
\hline 7 & 3.25 & 0.8 & 0.0175 & 0.27 & 0.017 & 0.01746 \\
\hline 8 & 3.00 & 1.0 & 0.0213 & 0.33 & 0.021 & 0.02127 \\
\hline 9 & 2.75 & 1.2 & 0.0254 & 0.40 & 0.025 & 0.02535 \\
\hline 10 & 2.50 & 1.4 & 0.0296 & 0.47 & 0.030 & 0.02962 \\
\hline 11 & 2.25 & 1.6 & 0.0319 & 0.53 & 0.032 & 0.03191 \\
\hline 12 & 2.00 & 1.8 & 0.0337 & 0.60 & 0.034 & 0.03366 \\
\hline
\end{tabular}

Tabel 7. Maju dan mundurnya garis tebing pada tinggi air $\mathrm{h}=2.0$ meter

\begin{tabular}{ccccccc}
\hline No. titik & $\mathrm{h}_{\mathrm{b}}$ & $\mathrm{d}_{\mathrm{r}}$ & $\mathrm{q}_{\mathrm{br}}$ & $\Delta \mathrm{r}$ & $\varepsilon_{\mathrm{i}, \mathrm{j}}$ & $\Delta \mathrm{B}_{1, \mathrm{j}}$ \\
\hline 1 & 4.75 & 0.5 & 0.0008 & 0.17 & 0.001 & 0.00062 \\
\hline 2 & 4.50 & 0.4 & 0.0020 & 0.13 & 0.002 & 0.00185 \\
\hline 3 & 4.25 & 0.3 & 0.0042 & 0.10 & 0.004 & 0.00401 \\
\hline 4 & 4.00 & 0.2 & 0.0076 & 0.07 & 0.007 & 0.00741 \\
\hline 5 & 3.75 & 0.4 & 0.0125 & 0.13 & 0.012 & 0.01236 \\
\hline 6 & 3.50 & 0.6 & 0.0193 & 0.20 & 0.019 & 0.01913 \\
\hline 7 & 3.25 & 0.8 & 0.0759 & 0.27 & 0.076 & 0.07570 \\
\hline 8 & 3.00 & 1.0 & 0.0977 & 0.33 & 0.098 & 0.09756 \\
\hline 9 & 2.75 & 1.2 & 0.1196 & 0.40 & 0.119 & 0.11942 \\
\hline 10 & 2.50 & 1.4 & 0.1415 & 0.47 & 0.141 & 0.14127 \\
\hline 11 & 2.25 & 1.6 & 0.1633 & 0.53 & 0.163 & 0.16313 \\
\hline 12 & 2.00 & 1.8 & 0.1852 & 0.60 & 0.185 & 0.18499 \\
\hline
\end{tabular}




\subsection{Hasil Analisis Maju dan Mun- durnya Garis Tebing}

Gambaran kondisi dasar dan tebing sungai setelah pengaliran debit pada tinggi muka air mencapai $h=4.5$ meter bisa dilihat pada tabel 8 .

Hasil analisis perubahan dimensi sungai ini memuat kondisi perubahan dimensi sungai yang diwakili oleh tujuh belas cross section, masing-masing cross section ditinjau dua belas titik tinjauan (point node). Perubahan dimensi sungai yang diakibatkan oleh tiga kondisi muka air yaitu pada tinggi muka air $\mathrm{h}=$
4.5 meter, 3.0 meter, dan 2.0 meter seperti yang terlihat pada tabel 9 dan gambar 4.

\section{Simpulan}

1. Degradasi terbesar pada tebing dengan sudut lereng terbesar dan berada pada cross section bagian luar.

2. Agradasi terbesar tidak selalu pada tebing dengan sudut lereng terkecil dan berada pada pada cross section bagian dalam.

Tabel 8. Kondisi dasar dan tebing sungai pada elevasi muka air $\mathrm{h}=4.5$ meter

\begin{tabular}{ccccccccc}
\hline $\begin{array}{c}\text { No. } \\
\text { titik }\end{array}$ & $\begin{array}{c}\text { H } \\
(\mathrm{m})\end{array}$ & $\begin{array}{c}\text { MT } \\
\text { Kond 0 }\end{array}$ & $\begin{array}{c}\text { MT } \\
\text { Kond 1 }\end{array}$ & $\begin{array}{c}\text { MT } \\
\text { Kond 2 }\end{array}$ & $\begin{array}{c}\text { MT } \\
\text { Kond 3 }\end{array}$ & $\begin{array}{c}\text { MT } \\
\text { Kond 4 }\end{array}$ & $\begin{array}{c}\text { MT } \\
\text { Kond 5 }\end{array}$ & $\begin{array}{c}\text { MT } \\
\text { Kond 6 }\end{array}$ \\
\hline 1 & 4.50 & -119.72 & -119.72 & -119.72 & -119.72 & -119.72 & -119.72 & -119.72 \\
\hline 2 & 3.50 & -103.72 & -103.72 & -103.72 & -103.72 & -103.72 & -103.72 & -103.72 \\
\hline 3 & 2.20 & -87.72 & -87.72 & -87.72 & -87.72 & -87.72 & -87.72 & -87.72 \\
\hline 4 & 1.40 & -71.72 & -71.72 & -71.72 & -71.71 & -71.71 & -71.71 & -71.71 \\
\hline 5 & 1.20 & -55.72 & -55.72 & -55.71 & -55.71 & -55.71 & -55.71 & -55.70 \\
\hline 6 & 0.20 & -39.72 & -39.71 & -39.71 & -39.70 & -39.70 & -39.70 & -39.69 \\
\hline 7 & 0.40 & -26.39 & -26.38 & -26.38 & -26.37 & -26.37 & -26.36 & -26.36 \\
\hline 8 & 1.50 & -13.05 & -13.05 & -13.05 & -13.04 & -13.04 & -13.04 & -13.04 \\
\hline 9 & 2.00 & 0.28 & 0.28 & 0.28 & 0.28 & 0.29 & 0.29 & 0.29 \\
\hline 10 & 2.50 & 13.61 & 13.62 & 13.62 & 13.62 & 13.62 & 13.62 & 13.62 \\
\hline 11 & 3.50 & 26.95 & 26.95 & 26.95 & 26.95 & 26.95 & 26.95 & 26.95 \\
\hline 12 & 4.50 & 40.28 & 40.28 & 40.28 & 40.28 & 40.28 & 40.28 & 40.28 \\
\hline
\end{tabular}

Tabel 9. Resume perubahan kondisi dasar dan tebing sungai pada cross section No. 17

\begin{tabular}{cccccc}
\hline No. titik & $\mathrm{H}(\mathrm{m})$ & MT Kond 0 & Hair $=4.5 \mathrm{~m}$ & Hair $=3.0 \mathrm{~m}$ & Hair $=2.0 \mathrm{~m}$ \\
\hline 1 & 4.50 & -119.72 & -119.72 & -119.72 & -119.72 \\
\hline 2 & 3.50 & -103.72 & -103.72 & -103.59 & -103.59 \\
\hline 3 & 2.20 & -87.72 & -87.72 & -87.56 & -87.56 \\
\hline 4 & 1.40 & -71.72 & -71.71 & -71.53 & -71.53 \\
\hline 5 & 1.20 & -55.72 & -55.70 & -55.51 & -55.51 \\
\hline 6 & 0.20 & -39.72 & -39.69 & -39.50 & -39.50 \\
\hline 7 & 0.40 & -26.39 & -26.36 & -26.16 & -26.16 \\
\hline 8 & 1.50 & -13.05 & -13.04 & -12.84 & -12.84 \\
\hline 9 & 2.00 & 0.28 & 0.29 & 0.47 & 0.47 \\
\hline 10 & 2.50 & 13.61 & 13.62 & 13.77 & 13.77 \\
\hline 11 & 3.50 & 26.95 & 26.95 & 26.95 & 26.95 \\
\hline 12 & 4.50 & 40.28 & 40.28 & 40.28 & 40.28 \\
\hline
\end{tabular}




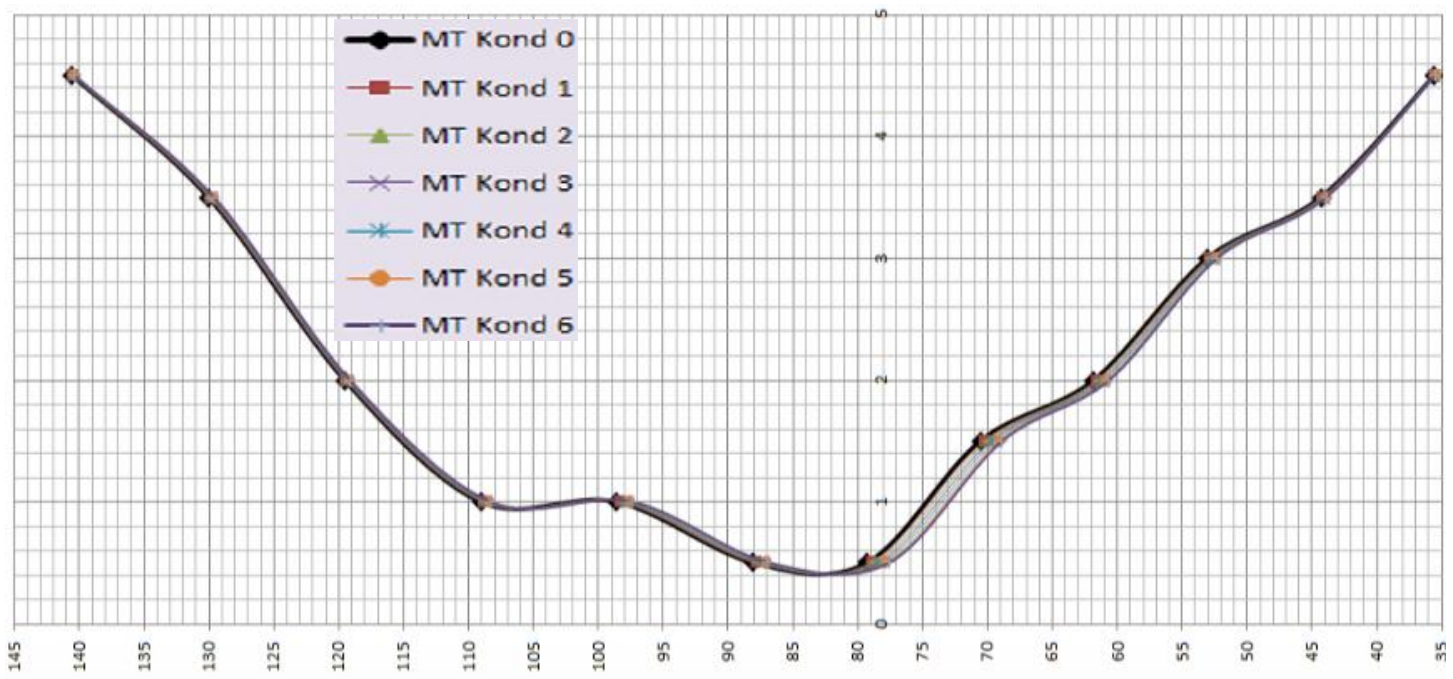

Gambar 4. Perubahan geometri sungai pada cross section 17 kondisi banjir $\mathrm{H}=4.5 \mathrm{~m}$

3. Bisa terjadi kondisi bolak-balik, terjadi degradasi pada kedalaman air $\mathrm{h}=4.5$ meter dan agradasi pada kedalaman air 3.0 atau 2.0 meter. Contoh pada cross section 1 di titik 7, 8, 9, dan 10 .

4. Pergeseran yang sangat kecil sekali dan mendekati angka 0 pada tinggi air $\mathrm{h}=2.0$ meter pada cross section 10 sampai dengan 17.

\section{Daftar Pustaka}

Abad, J. and Garcia, M. H., (2006). RVR Meander: A Toolbox for Remeandering of Channelized Streams. Computers \& Geosciences, 32, 92-101.

Briaud J. L., Ting, F., Chen, H. C., Cao, Y., Han, S. W., and Kwak, K. W., (2001c). Erosion Function Apparatus for Scour Rate Predictions. Journal of Geotechnicaland Geovironmental Engineering, 127(2), 105-113.

Harrell, C., B.K. Ghosh and R.O. Bowden, Jr., (2003). Simulation
Using Promodel, 2nd ed., McGraw-Hill. Singapore.

Hooke, J. M., (1980). Magnitude and Distribution of Rates of River Bank Erosion. Earth Surface Processes, 5(2), 143-157.

Hudson, P. F., and Kesel, R. H., (2000). Channel Migration and Meanderbend Curvature in the Lower Mississippi River Prior to Major Human Modification, Geology, 28(6), 531-534.

H.J. Overbeek. (1978). Revier Engineering and Flood Protection, Bangkok: Asian Institut of Technology.

Hsieh Wen Shen, River Mechanics Volume I, H. W Shen Book Company, Colorado.

Park Namgyu. (2007). A Prediction of Meander Migration Based on Large Scale flume Tests In clay. Ph.D. Dissertation. Texas A\&M University.

P.Ph. Jansen, L. Van Bendegom, J Van Den Berg, M De Vries, A Zanen. (1979). Principles of River 
Engineering The non-tidal alluvial river, London: Pitman Publishing Limited. 